\title{
The Psychiatrist on the Parole Board
}

PAtrick G. McGrath, formerly Physician Superintendent, Broadmoor Hospital; 18 Heathermount Drive, Edgcumbe Park, Crowthorne, Berkshire

It is some years since Dr Henry Rollin published, in the Prison Medical Journal, an address he gave to prison doctors on the Role of The Psychiatrist on the Parole Board. ${ }^{1}$ Since then, there have been changes in policy and practice, and it may be opportune now to bring the work up to date, and to the notice of a generation of psychiatrists who might some day have the privilege and pleasure of serving on the Board.

The Parole Board was constituted by the Criminal Justice Act 1967, Part III, and is an independent body, appointed by the Home Secretary, to advise him on the release on licence of prisoners, the conditions of such licences, and their variation or cancellation. It should be emphasised here that the Board's function is advisory only; executive authority rests solely in the hands of the Secretary of State, [save in a very small number of recalled prisoners]. ${ }^{2}$

At present there are over 50 members of the Board. By the Statute, the Parole Board includes among its members "a registered medical practitioner who is a psychiatrist" as well as a holder (or former holder) of judicial office, a probation officer and a criminologist. In addition there are "independent" members; this group draws largely from members of voluntary bodies with relevant functions, retired officials and senior police officers, and so on. The selection of psychiatrists to sit on the Board is something of a mystery; somewhat surprisingly, the Royal College of Psychiatrists does not appear to be consulted. In a three year term, however, all the psychiatrists on the Board were experienced, and if not labelled 'forensic psychiatrists,' at least had evinced a special interest in forensic work. None was a blinkered devotee of any one of the more esoteric schools within the discipline.

The Board sits in 'panels' of four of five members, not always including a psychiatrist, to consider cases. On 'lifer' panels, however, by convention rather than law, there is always a High Court Judge and a psychiatrist. ${ }^{3}$ Panels normally consider some $27-30$ determinate sentence cases in a meeting (or up to 16 life sentence cases). In a randomly selected, but not atypical, three month period April-June 1985, 66 such panels met, mainly in London, but some in Manchester and Cardiff, and a psychiatrist was a member of 46 of them; in this period, eight panels considered 'lifer' cases. During such a period, an individual psychiatrist might expect to sit on eight panels. His tour of duty will be three years.

The work is not over-onerous, but does involve many hours preparation for each panel; the reading and digestion of reports from many sources; formulation of opinions; preparation of some cases, about one in four, in depth, to be able to present them to the rest of the panel. (Each member of the panel 'leads' on, i.e. presents, cases in turn). The panel discussion itself is salutary as well as stimulating. The psychiatrist is engaged in debate, sometimes very lively, with peers in different disciplines; a situation far removed from the cosy case conferences which have a background of the knowledge, shared by the whole team, that the consultant psychiatrist, as responsible medical officer, at the end of the day, shoulders the clinical responsibility.

In those many cases in which there is a question about the prisoner's emotional maturity and balance, intellectual equipment, or motivation, the panel looks to the psychiatrist for advice on any one -or more - of a number of dimensions, of which the following are but examples:

(1) Professional evaluation of the prisoner's emotional development and future growth.

(2) Interpretation of medical reports. Occasionally, and regrettably, it is necessary to point out deficiencies in the amount of information given by very hard-pressed doctors in busy remand prisons; (and the psychiatrist member may be asked to formulate a tactful request to the Director of Prison Medical Services for a more informative report.)

(3) Particularly on lifer panels, he may be asked to provide the basis for advice to be offered to the Prison Department on management strategies.

(4) Contribution of knowledge on the epidemiology, aetiology, and prognosis of behavioural patterns which are not necessarily pathological.

(5) Offering of such personal knowledge as he has of the personality, reliability and idiosyncrasies of writers of psychiatric reports. (In this context, I once sought, and received, assurance from a High Court Judge member of a panel that anything said in the Board room was privileged).

(6) Very occasionally indeed (once only in my stint on the Board) going to see a prisoner and reporting back to the Board.

(7) Specialised knowledge of the causes, symptoms and effects of alcohol and drug abuse; possible treatments and outlook.

Panels often ask the psychiatrist about the virtue of inserting a 'treatment' clause into the conditions of parole. This is an issue surrounded by difficulties, to which the Board addressed itself in 1978, and on which it circulated guidelines. The psychiatric member should assure himself that the eminently sensible advice is followed: namely, that the prisoner is aware of, and consents to, the provision; that appropriate arrangements have been made, and the consent of the doctor expected to carry out the treatment has been obtained.

Above all, the psychiatrist, as an individual and as a member of the Board, must address himself to the 
protection of the public, and play his full part-sometimes even the predominant part-in the assessment of dangerousness. "He can not, of course, carry out his professional job of assessment in a social vacuum". " This is what parole is all about-a point emphasised by the then Home Secretary in a written answer in Parliament on 30 November 1983-"I look..... to the Parole Board for advice on risk". ${ }^{3}$ This imposes on the psychiatrist an obligation to keep his judgements within an irrefragable framework of safety; and he must control his natural inclination to do his best for the health and welfare of the incarcerated prisoner/patient. Herein, perhaps lies the virtue of doing all the work on paper, without the intrusion of counter-transference, be it positive or negative.

This raises the crucial, thousand dollar question-are psychiatrists good at assessing dangerousness?. That distinguished criminologist and now Board member, Professor Walker obviously thought not, when he wrote, "There should always be enough non-psychiatrists to outvote the psychiatrists". ${ }^{5}$ On the whole, psychiatrists tend to be over-cautious, as witness the Baxtrom case in USA in 1966. By a legal ruling, 969 patients adjudged by psychiatrists to be dangerous were released-their subsequent criminal careers did not differ, on an arrest rate comparison, from a matched sample of the general population. ${ }^{6} \mathrm{Kress}^{7}$ argues cogently that assessment of dangerousness is not properly the province of psychiatry. Fottrell ${ }^{8}$ said that much greater accuracy would be achieved by predicting all patients as non-violent. Bradley' and Bluglass ${ }^{10}$ say outright that 'The psychiatrist is not very good at predicting dangerousness' and Dell ${ }^{11}$ is sceptical of psychiatric predictions; “. . . . might depend less on the patient's characteristics than those of the RMO (Consultant Psychiatrist)". The late, great, forensic psychiatrist Dr P. D. Scott ${ }^{12}$ wrote of dangerousness as "an unpredictable tendency.... to inflict serious, irreversible injury" and that "existing predictive scales are clinically unreliable".

Sir Hugh Forbes, ${ }^{13}$ a one time High Court Judge member of the Board, admits the value of psychiatric presence on the panel, but is sceptical about his infallibility "In deciding these questions (of dangerousness) the opinion of the psychiatrist is of very considerable value, but cannot be seen as entirely conclusive".

The psychiatrist joining the Board will meet with a most courteous welcome, and with respect. He will retain that respect as long as he remembers that he is not omniscient, but that he can err in assessment. Armoured by that humility, he will have a most enjoyable three years, in the course of which he will learn much of value to his professional life.

\section{REFERENCES}

'RoLun, H. R. (1972) Role of the psychiatrist on the Parole Board. Prison Medical Journal, April, 37-41.

${ }^{2} \mathrm{McCABg}$, S. F. (1985) The powers and purposes of the Parole Board. Criminal Law Review, August, 489-499.

${ }^{3}$ Report of the Parole Board (1984) London: HMSO.

4MCGrath, P. G. (1968) The mentally abnormal offender. In Ciba Symposium, pp. 124-129. London: J. A. Churchill.

SWALKER, N. (1978) Dangerous people. International Journal of Law and Psychiatry, I, 37-50.

'Steadman, H. J. \& Cacozza, J. J. (1973) The criminally insane patient-who gets out? Social Psychiatry, 8, 230-238.

'Kress, F. (1979) Evaluation of dangerousness. Schizophrenia Bulletin, 5, 212-215.

'FottrelL, E. (1982) Review of Dangerousmess: Psychiatric Assessment and Management (ods. J. R. Hamilton \& H. Freeman). British Journal of Psychiatry, 141, 543.

'BRADLEY, J. J. (1982) Dangerousness-psychiatric assessment and management. Medico-Legal Journal, I, 125-126.

${ }^{10}$ BLUGLAss, R. (1985) Lecture to the Howard League, November 1985.

${ }^{11}$ DeLL, S. (1980) Transfer of Special Hospital patients to the NHS. British Journal of Psychiatry, 136, 222-234.

${ }^{12}$ ScotT, P. D. (1977) Assessing dangerousness in criminals. British Journal of Psychiatry, 131, 127-142.

${ }^{13}$ Forbes, H. (1982) In Dangerousmess: Psychiatric Assessment and Management (eds. J. R. Hamilton \& H. Freeman), pp. 110-113. London: Gaskell (Royal College of Psychiatrists).

\section{Diploma in Psychotherapy}

Applications are invited for a multi-disciplinary course in psychotherapy, starting its seventh annual intake in October 1987. The course is part-time, extending over two years, and leading to the University qualification of Diploma in Psychotherapy. Application forms and further details are available from the Secretary, Sub-Department of Clinical Psychology, New Medical School, University of Liverpool, Ashton Street, PO Box 147, Liverpool L69 3BX. Completed application forms should be returned by 30 April 1987.

\section{B.B. Zeitlyn Psychotherapy Training Fund}

A fund has been set up for those living in Cambridge and East Anglia who wish to train as psychotherapists. Monies are available as an interest free loan to be repaid within three years of completion of training. Applications should be received by 21 April and loans to successful applicants will be offered from 1 October 1987. Further details are available from the Honorary Secretary, B.B. Zeitlyn Psychotherapy Training Fund, 16 Milner Road, Comberton, Cambridge CB3 7DE. 